\title{
Role of Suryanamaskara in Polycystic Ovarian Disease- A Case Study
}

\author{
Case Study
}

\author{
Vinaya V Potdar ${ }^{1^{*}}$, Pawar $\mathbf{J J}^{2}$
}

1.Post-graduate Scholar, Kriya Sharir Department, Government Ayurved College Nanded Maharashtra.

2. Associate Professor Kriya Sharir Department, Government Ayurved College Nanded Maharashtra.

\begin{abstract}
The patient of Polycystic Ovarian Disease(PCOD) came at hospital, had complaint of irregular menstrual cycle, stress, obesity, hairfall. Sedentary lifestyle and Apana vayu vikruti were observed in patient which is responsible for vitiation of Tridosha and Rasa, Meda, Artava Dhatu as well as their Srotasa. In such condition Yoga posture of Suryanamsakara were advised and follow up taken for four month. Some significant results were observed. By practicing Suryanamaskara with Pranayama exercise were helpful to rejuvenation of physical and mental health by increasing the metabolic function of Agni and Satva Guna in the body. Also facilitate to regulate menstrual cycle, reduce BMI (obesity) and hairfall by removing obstruction in the srotasa. So it is advisable in the management of PCOD.
\end{abstract}

Keywords: Suryanamaskara, PCOD, Apana vayu, Obesity

\section{Introduction}

Polycystic Ovarian Disease (PCOD) is an endocrine disorder associated with metabolic alteration in women of reproductive age. It is most common cause of infertility, with physical, psychological \& hormonal imbalance. The prevalence rate of Polycystic Ovarian disease (PCOD) in India is $9.13 \%$. It is characterised by irregular, scanty menstruation, depression, obesity, acne, hair fall cystic ovary, blood sugar imbalance etc. various factor responsible for Polycystic Ovarian Disease, but stress \& lack of exercise are also most important factor in exaggerating Polycystic Ovarian Disease(1).

Stress, anxiety \& lack of exercise are etiological factor of Rasavaha \& Medovah Srotodushti respectively (2). According to Ayurveda, term Granthi is nothing but cyst. Sushrut Acharya stated that vitiated Rasa, Rakta, Meda Dhatu \& vitiated Kapha and Vata Dosha are responsible to create Granthi. But Meda dhatu also have main role to create Granthi(3). Today's changing lifestyle, irregular diet, regimen, habits are etiological factors for vitiation of Tridosha \& Rasa, Rakta, Meda Dhatu \& Vega-dharana also responsible for Apana Vayu Vikruti. Results-Artavavaha Srotodushti \& irregular menstrual cycle(4). Acharya Vagbhata stated that regular Vyayama strengthens body, makes it flexible, increases the biochemical function of $\mathrm{Agni}$ and burns excess Meda Dhatu (5).

So, Suryanamaskara (12 yoga poses) as Vyayama may help to regulate biochemical function of $\mathrm{Agni}$, correct the fat metabolism i.e. Meda dushti \& improve the lymphatic \& circulatory function of body i.e. Rasa, Rakta dushti. Also by synchronisation of breathing

*Corresponding Author:

Vinaya V Potdar

PG scholar (kriya sahrir )

Govt. Ayurved College Nanded.

Email: vinayavpotdar@gmail.com

Phone No: +91 - 9921435863 exercise with chanting of Mantra in each 12 yoga posture helps to increase the Satva Guna \& decreases the Tamasik \& Rajo Guna in the body(6). Thus it is effective in keeping ones ovary \& uterus healthy along with solving of issues such as infertility, especially weight gain \& psychological problems.

For this purpose, Surya Namaskara is advised to the patient having Polycystic Ovarian Disease and it was observed that 12 yoga poses of Surya Namaskara were effective in prevention \& management of Polycystic Ovarian Disease. It is one of the important refreshing \& rejuvenating modalities which can root out stress completely. It also helps to reduce the hair fall \& excess weight gain in Polycystic Ovarian Disease.

\section{Aims and Objectives}

To evaluate the role of Suryanamaskara in management of Polycystic Ovarian Disease.

\section{Materials and Methods}

The study was conducted in a single female patient of 25 years came at hospital on 25/6/16.

\section{Case Report}

Personal History-

Name- xyz, Occupation- private job, Prakruti Kaph Pradhan Pittanubandhi, Age -25 yrs, EducationMCA, Agni- Madhyam, Sex- Female, Height - 5ft, Koshth- Madhyam, Marital status- 2yr.before, Weight$70 \mathrm{~kg}$ (BMI-30.14), Diet - Mix diet, Bala- Madhyam, Nidra-Atinidra.

The case study was conducted in a patient of infertility due to polycystic ovarian disease complaining - Irregular menses (since 1 yr), Obesity (sudden weight gain in $1 \mathrm{yr}$ ), Mood swing (since 6 month), Hair loss (since $1 \mathrm{yr}$ ).

\section{History of present illness:}

Patient had complaints since last $4 \mathrm{yr}$, but at the beginning complaints of only irregular menses and 
sudden weight gain were present, USG report with mild small cystic ovary. Patient had taken hormonal treatment $\&$ is still going at infertility centre,Bangalore. USG was done again after $2 y r s$, it showed polycystic ovary. Also severe weight gain, mood swings, irritability, irregular and scanty menstruation were seen. For this purpose, patient came for supportive management of PCOD, then we advised daily 12 posture of Surya Namaskara in increasing order for 4 months regularly \& results were observed. Past history: History of operative for squint before 2 yr. Premenstrual history: Irregular, 2 to 3 month amenorrhoea, 2 to 3 day scanty bleeding with mild abdominal pain \& discomfort. LMP: 3/6/2016. Ashtavidha parikshan: Nadi - 78/minute, Mala Samyaka, Mutra -Samyaka, Jivha -Nirama, Shabdh clear pronunciation, Sparsha-Samshitoshna, Druk - h/o myopia \& squint, A akruti-Sthulakruti (obese).

\section{Nidan Panchaka: (in patient)-}

(1)Hetu -Excess sweet diet, day-sleep, lack of exercise, mutra \& purisha vega dharana. (2)PurvaroopAnartava, Gaurava (heaviness feeling), khalitya (hair loss). (3)Roopa - Anartava, sudden weight gain, cystic ovary in USG. (4)Upshaya -Regular exercise. (5) Samprapti-Harmful Meda and Kapha causes vitiation of Artava vaha Srotasa.

Systemic examination - CVS, RS, CNS - NAD, BP130/80 mm ofHg, PR- 80/Min.

Investigation : $\mathrm{Hb}-12.8 \mathrm{gm} / \mathrm{dl}$.

Treatment planned -

Daily at early morning 12 poses of Suryanamaskara were advised with empty stomach beginning with 5 rounds of Suryanamaskara and then slowly increasing the number, Duration - 4 month, Suryanamaskara were contraindicated during menstruation.

\section{Observations}

Table 1: Observation of Body Weight

\begin{tabular}{|c|c|c|c|}
\hline $\begin{array}{l}\text { Exercise } \\
\text { started } \\
\text { on } \\
\text { date: }\end{array}$ & $\begin{array}{l}\text { Days of } \\
\text { Suryanamas } \\
\text { kara }\end{array}$ & $\begin{array}{l}\text { No. of } \\
\text { Suryanama } \\
\text { skara done } \\
\text { by } \\
\text { patient }\end{array}$ & $\begin{array}{l}\text { Wt. } \\
\text { measured }\end{array}$ \\
\hline \multirow[t]{8}{*}{ 1/July/16 } & $1^{\text {st }} 15$ days & 5 & $70 \mathrm{~kg}$ \\
\hline & $\begin{array}{l}15^{\text {th }} \text { to } 30^{\text {th }} \\
\text { day }\end{array}$ & 8 & $69.2 \mathrm{~kg}$ \\
\hline & $\begin{array}{l}30^{\text {th }} \text { to } 45^{\text {th }} \\
\text { day }\end{array}$ & 11 & $68 \mathrm{~kg}$ \\
\hline & $\begin{array}{l}45^{\text {th }} \text { to } 60^{\text {th }} \\
\text { day }\end{array}$ & 14 & $66.8 \mathrm{~kg}$ \\
\hline & $\begin{array}{l}60^{\text {th }} \text { to } 75^{\text {th }} \\
\text { day }\end{array}$ & 17 & $65 \mathrm{~kg}$ \\
\hline & $\begin{array}{l}75^{\text {th }} \text { to } 90^{\text {th }} \\
\text { day }\end{array}$ & 20 & $64.2 \mathrm{~kg}$ \\
\hline & $\begin{array}{l}90^{\text {th }} \text { to } 105^{\text {th }} \\
\text { day }\end{array}$ & 23 & $63.8 \mathrm{~kg}$ \\
\hline & $\begin{array}{l}105^{\text {th }} \text { to } \\
120^{\text {th }} \text { day }\end{array}$ & 25 & $62 \mathrm{~kg}$ \\
\hline
\end{tabular}

Table 2: Observation of menstrual cycle

\begin{tabular}{|c|c|}
\hline Before & After Suryanamaskara. \\
\hline \multirow{4}{*}{$\begin{array}{l}\text { Irregular \& } \\
\text { at } 2 \text { to } 3 \\
\text { month } \\
\text { interval } \\
\text { with } \\
\text { abdominal } \\
\text { pain. }\end{array}$} & $\begin{array}{l}\text { Menses came at } 40^{\text {th }} \text { day ( date }: 10 \\
\text { aug } 2016 \text { ) } \\
1 \text { day bleeding } 2^{\text {nd }} \& 3^{\text {rd }} \text { day spotting, } \\
4^{\text {th }} \text { day normal no bleeding } \\
\text { Mild abdominal pain }\end{array}$ \\
\hline & $\begin{array}{l}\text { Menses came at } 36^{\text {th }} \text { day (date: } 14 \\
\text { sep } 2016 \text { ) } \\
2 \text { day bleeding } \& 3^{\text {rd }} \text { day spotting }, 4^{\text {th }} \\
\text { day normal no bleeding. No } \\
\text { abdominal pain }\end{array}$ \\
\hline & $\begin{array}{l}\text { Menses came at } 31^{\text {st }} \text { day (date: } 14 \\
\text { oct } 2016 \text { ) } \\
2 \text { day bleeding } \& 3^{\text {rd }} \text { day spotting }, 4^{\text {th }} \\
\text { day normal no bleeding. } \\
\text { No abdominal pain. }\end{array}$ \\
\hline & $\begin{array}{l}\text { Menses came at } 31^{\text {st }} \text { day ( Date: } 13 \\
\text { nov } 2016 \text { ) } \\
2 \text { day bleeding } \& 3^{\text {rd }} \text { day spotting }, 4^{\text {th }} \\
\text { day normal no bleeding. } \\
\text { No abdominal pain. }\end{array}$ \\
\hline
\end{tabular}

Table 3: Parameter assessment before \& after Surya Namaskara

\begin{tabular}{|c|c|}
\hline Before & After \\
\hline $\begin{array}{l}\text { Weight:70 kg (BMI- } \\
30.14)\end{array}$ & $62 \mathrm{~kg}$ (BMI- 26.69) \\
\hline $\begin{array}{l}\text { Irregular menses } 2 \text { to } 3 \\
\text { month amenorrhoea } \\
\text { with abdomen pain }\end{array}$ & $\begin{array}{l}\text { Painless, Regular at } 30 \\
\text { to } 32 \text { th day }\end{array}$ \\
\hline $\begin{array}{l}\text { Stress/ irritability/mood } \\
\text { swing }\end{array}$ & $\begin{array}{l}\text { Feeling relaxed, fresh \& } \\
\text { mentally stable. }\end{array}$ \\
\hline $\begin{array}{l}\text { USG : Bilateral Poly- } \\
\text { cystic ovary } \\
\text { (Ovaries are enlarged in } \\
\text { size and shows polycys- } \\
\text { tic morphology } \\
\text { Rt ovary- } \\
4.19 \times 3.8 \times 3.44 \mathrm{~cm} \\
\text { Left ovary- } \\
4.10 \times 2.5 \times 3.30 \mathrm{~cm} . \text { ) }\end{array}$ & $\begin{array}{l}\text { Bilateral polycystic } \\
\text { morphology } \\
\text { Rt ovary }-3.4 \times 2.4 \times 3.4 \\
\mathrm{~cm} \\
\text { Left ovary- } 3.9 \times 1.7 \times 2.6 \\
\mathrm{~cm})\end{array}$ \\
\hline 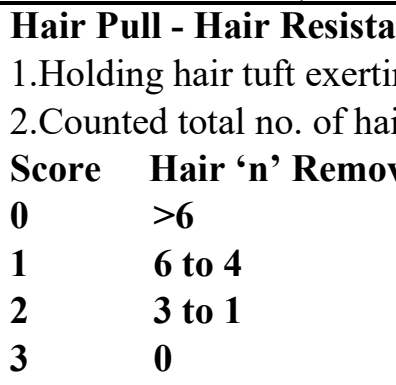 & $\begin{array}{l}\text { ce test ( } 7) \text {. } \\
\text { g constant traction. } \\
\text { s removed. } \\
\text { ed in } 3 \text { Areas of Head }\end{array}$ \\
\hline $\begin{array}{l}\text { Much amount of Hair } \\
\text { loss during combing of } \\
\text { hair, less voluminous. } \\
\text { Hair pull test - score } 0 \\
\text { (hair removed }>6 \text { ) }\end{array}$ & $\begin{array}{l}\text { Decreased the hair loss } \\
\text { during combing of hair. } \\
\text { Hair pull test -score } 2 \\
\text { (hair removed } 3-1 \text { ) }\end{array}$ \\
\hline
\end{tabular}




\section{Discussion}

Polycystic Ovarian Disease (PCOD) is a common endocrine disorder occurring during female reproductive age. It is characterised by number of heterogeneous clinical \& biochemical features. Menstrual dysfunction, obesity, alopecia, acne, infertility \& cystic ovary, hormonal imbalance are the features of Polycystic ovarian Disease. In addition to these endocrine abnormalities, metabolic alteration is also associated with Polycystic Ovarian Disease \& it may predispose the range of diseases with attendant morbidity \& mortality risk, So it is important to consider the syndrome in terms of both endocrine \& metabolic aspect.

According Ayurveda, Polycystic Ovarian Disease is the kaphaja disorder. Here term Granthi is used for cyst (8). Stress, anxiety \& lack of exercise, sedentary lifestyle were observed in patient which is responsible for Tridosha \& Dhatu Dushti \& Ama (toxin) production in the body (9). As well as suppression of natural urges also found as hetu in patient which lead to Apana Vayu Vikruti (10). Excess Vitiated kapha and Ama obstruct vata \& pitta. Hence Apana vayu as well as Rasa, Artava \& Meda dhatu get vitiated due to sticky properties of vitiated kapha and Ama, which creates obstruction in Artava-vaha srotas (11). So it results in Pratilom or Mudha Gati of Apana Vayu, which responsible for inhibition of Artava Nishkramana. Excess vitiated Meda dhatu get deposited due to similar characteristics of kapha dosha. It responsible for Medovaha Sroto Dusti \& result Obesity. Vitiated Meda \& Rasa Dhatu, Kapha and Vata dosha are responsible for pathogenesis of cyst in the ovary (12). Excess kapha and Ama obstruct the hair follicle leading to inhibition of hair growth \& result in hair loss.

Vyayam karma (exercise) is described in Dinacharya Adhyaya (13). The regular practice of Suryanamaskara as Vyayam karma corrected the Rasa Dushti resulting in feeling prasanna mana, laghvata (lightweightness) in the patient. It also resulted in burning of excess Meda dhatu as well as painless bleeding due to Apana Anulomana. Also by synchronisation of breathing exercise with chanting of Mantra in each 12 yoga posture, it improves the mental clarity by increasing fresh oxygenated blood to brain.

In this way, 12 yoga poses of Suryanamaskara were helpful in patient to regulate menstrual cycle, reduce excess weight, reduce the size of cyst in ovary $\&$ making her mentally stable .

\section{Conclusion}

The study revealed that, Suryanamaskara exercise is significant in the management of polycystic ovarian disease. With Pranayama exercise it is enable to reduce the Rajasik and Tamasik phase of mind which gives real mental health. Also it act as booster of metabolic function of $A g n i$ and helpful to remove the obstruction of harmful Kapha and Meda in Artavavaha Srotasa. So it is preferably advisable in Polycystic Ovarian Disease for physical and mental health.

\section{References}

1. www.gyanunlimited.com

2. Acharya priyavat Sharma, Charaka Samhinta of Agnivesha with Ayurved Dipika commentary of Chakradatta part 1.Edition $7^{\text {th }}$ edition varanasi chaukhamba Prakashan 2002, Page No.595.

3. Rajeshwardutta Shatri, Charaka Samhita Viddyotini hindi vyakhya $2^{\text {nd }}$ part , varanasi chaukhamba prakashana, Page No.372.

4. Vaidy Ydunandan Upadhyay, Ashtanghrudayam of Vagbhata Vidyotini hindi commentary, varanasi chaukhamba 2008. Page No.43.

5. Vaidy Ydunandan Upadhyay, Ashtanghrudayam of Vagbhata Vidyotini hindi commentary, varanasi chaukhamba 2008, Page No.25.

6. Motilal Banarasi Das, Patanjal Yog Darshan 3rd edition 1980 varanasi,Page No.7,265,66.

7. Luigi Rigano \& Chiara Andolfatto,CLA Glutathione \& Sodium DNA for reducing Hair loss, Cosmetics \& Toiletries, 10 october 2007,vol.122., Page no.7.

8. Bramhananda Tripathi, Madhavnidana Madhukosha vhyakhya purvardha, 2007 varanasi chaukhamba prakashan Page No.86.

9. Bramhanand Tripathi, Madhav Nidanam Madhukosh vyakhya volume I, varanasi chaukhmba prakashan 2007 Page No.295.

10.Vaidy Ydunandan Upadhyay, Ashtanghrudayam of Vagbhata Vidyotini hindi commentary, varanasi chaukhamba 2008. Page No.43.

11.Sharma PV, Ashtanghrudayam with commentaries (sarvang sundar ) of Arun Dutta \& (Ayurved rasayana) of Hemadri, $8^{\text {th }}$ edition 1998 varanasi chaukhmba prakashan.Page No.216.

12.Kaviraj Ambikadutta Shastri, Sushrut Samhinta Ayurved tattva Sandipika Part I. Edition 2007 varanasi chaukhmba prakashan. Page No.270.

13. Vaidy Yadunandan Upadhyay, Ashtanghrudayam of Vagbhata Vidyotini hindi commentary, 2008 varanasi chaukhamba, Page No.25. 